\title{
PENERAPAN CLOUD STORAGE DALAM PERKULIAHAN FAKULTAS TEKNIK UNIVERSITAS PGRI MADIUN
}

\author{
Mei Lenawati, Hani Atun Mumtahana \\ Universitas PGRI Madiun \\ Jurusan Sistem Informasi, Fakultas Teknik, Universitas PGRI Madiun, Madiun \\ e-mail: mei.lenawati@unipma.ac.id
}

\begin{abstract}
Abstrak -Perkembangan teknologi komputer berbasis internet sekarang ini telah mengarah pada proses pengaplikasian sistem yang mudah dan hanya membutuhkan sedikit tenaga. Komputasi awan (cloud computing), yaitu gabungan pemanfaatan teknologi komputer dalam suatu jaringan dengan pengembangan berbasis internet yang mempunyai fungsi untuk menjalankan program atau aplikasi internet melalui komputer dengan koneksi internet. Internet memberikan kemudahan dalam bebagai segi pekerjaan, termasuk dalam lingkungan pendidikan. Pada perguruan tinggi dengan jumlah mahasiswa yang cukup banyak dengan lokasi yang berbeda, tidak jarang sering mengalami kesulitan dalam pengerjaan tugas kelompok dikarenakan domisili yang berjauhan dengan adanya internet mahasiswa dapat saling berkomunikasi meskipun dalam lokasi yang berbeda. Sharing Data dan penyimpanan data merupakan kegiatan yang sering dilakukan oleh mahasiswa dan dosen. Pada era modern ini, salah satu masalah yang sering terjadi adalah kehilangan data yang sangat penting dikarenakan hardware rusak, file terinfeksi virus sehingga file tidak bisa dibuka. Maka dari itu sangat diperlukan layanan cloud computing sebagai media penyimpanan yang dapat memback up seluruh data penting yang terjamin keamanannya dan dapat diupload maupun didownload dari mana saja
\end{abstract}

Kata kunci-Cloud Computing, Cloud Storage, sharing data

\section{PENDAHULUAN}

Universitas PGRI Madiun (UNIPMA) merupakan perguruan tinggi swasta yang diresmikan pada tanggal 3 januari 2017 dan memiliki 6 progam studi baru, salah satunya adalah program studi sistem informasi. Sebagai salah satu program studi yang bergerak di bidang teknologi dan informasi, sudah sepatutnya mampu mengimplementasikan lingkungan pendidikan berbasis teknologi[1]. Salah satunya dengan menggunakan E-learning, E-learning sendiri memiliki kelebihan dan kekurangan, untuk kelebihan dari E-learning diantaranya akses materi, komunikasi, \& uji kompetensi bisa dilakukan kapanpun dan dimanapun [2].

Dalam implementasinya Penggunaan Teknologi E-learning membutuhkan data base \& media penyimpanan tambahan yang bersifat cloud Computing/ berbasis komputasi awan. Data base sendiri Basis data merupakan komponen yang penting dalam sebuah sistem informasi modern[3]. Penyimpanan berbasis cloud ini memberikan banyak kemudaha, dimana pertukaran data dapat dilakukan tanpa batasan waktu dan tempat, selama terhubung dengan teknologi internet. Selain itu teknologi cloud computing memiliki kelebihan lain dimana data yang disimpan lebih terjaga keamanannya[4]. Penyimpanan data berbasis cloud juga memiliki keuntungan lain dimana pengguna dapat melihat data melalui telepon selular, tablet, atau komputer yang terhubung ke internet dan dapat menyediakan backup sehingga tidak akan pernah kehilangan data ketika telepon selular hilang atau komputer rusak[5].

Terdapat beberapa Penyimpanan berbasis cloud yang cukup dikenal lingkungan akademik di fakultas teknik diantaranya Dropbox, Google Drive, dan One Drive. Ketiga penyimpanan berbasis Cloud ini tentunya memiliki kelebihan dan kekurangan masing masing. Kelebihan dan kekurangan dari penyimpanan berbasis cloud ini dapat diukur dengan melakukan penyebaran kuisoner terhadap beberapa sampel responden yang terdiri dari mahasiswa dan dosen yang ada pada fakultas Teknik Universitas PGRI Madiun. Diharapkan dengan adanya penelitian ini dapat diketahui data secara kuantitatif mengenai pola perilaku dari pengguna penyimpanan berbasis Cloud di Fakultas teknik Universitas PGRI Madiun. 


\section{LANDASAN TEORI}

Cloud Computing adalah paradigma komputasi baru yang menjanjikan dan merupakan teknologi masa depan yang menyediakan banyak layanan komputasi yang belum pernah dirasakan sebelumnya[6].

Sebuah setup infrastruktur model Cloud Computing biasanya dikenali sebagai Cloud. Berikut adalah beberapa kategori layanan yang tersedia dari sebuah Cloud seperti:

\section{Infrastructure As A Service (IAAS) \\ 2. Platform As A Service (PAAS) \\ 3. Software As A Service (SAAS)}

Cloud Computing biasanya tersedia sebagai layanan kepada siapa saja di internet. Akan tetapi, varian yang disebut Private Cloud semakin popular untuk infrastruktur pribadi/private yang mempunyai atribut Cloud di atas. Cloud Computing berbeda dengan Grid Computing atau Paralel Computing, dimana Grid Computing dan Paralel Computing adalah lebih merupakan sebuah bagian dari prasarana fisik bagi penyediaan konsep Cloud Computing. Server konvensional akan di batasi oleh jumlah core processor, harddisk dan memory. Dengan keterbatasan fisik yang ada maka kita tidak mungkin membebani sebuah server konvensional dengan beban maksimal. Jika resource/sumber daya habis, maka biasanya kita harus menginstall ulang seluruh aplikasi dan data di server yang kapasitasnya lebih besar dan memigrasi semua aplikasi yang ada ke server yang baru. Ini akan membutuhkan waktu 1-2 hari untuk menyiapkan sebuah server baru, itupun kalau tidak ada masalah. Yang menarik dari Cloud Computing berbeda dengan server konvensional terutama:

Secara fisik berupa kumpulan hardware/server yang tersambung dalam sebuah jaringan (LAN/WAN). Tetapi dari sisi, pengguna dapat melihat sebagai sebuah komputer besar

2. Idealnya tidak ada batasan dengan kapasitas processor, kapasitas harddisk dan kapasitas memori.
3. Idealnya tidak ada batasan dengan berapa jumlah "hosting" server yang berjalan di belakangnya.

4. Menambahkan sebuah "hosting" hanya membutuhkan waktu beberapa menit saja.

5. Jika ada kekurangan resource (sumber daya), baik itu processor, harddisk maupun memory, dapat dengan mudah sekali menambahkan server tambahan dan langsung dapat berintegrasi ke jaringan Cloud. Butuh waktu sekitar 20 menit untuk menyiapkan server kosong/baru untuk dapat berintegrasi ke jaringan Cloud.

Cloud Storages adalah layanan penyimpanan file di internet yang mana file yang disimpan disitu dapat dikelola dari mana saja selama penggunanya terhubung ke cloud storage tersebut melalui internet. Konsep cloud storages sama seperti konsep file server pada suatu kantor perusahaan, hanya saja infrastruktur media storage tersebut dikelola oleh provider cloud dan pemanfaatannya dijadikan layanan penyimpanan file yang dapat diakses dari internet[7].

Beberapa jenis cloud storage adalah Dropbox, OneDrive, Google Drive, MEGA, iCloud, amazon dll.

Agar dapat menghubungkan akses pengguna dengan data yang tersimpan di internet Cloud computing memiliki 5 (lima) karakteristik, yaitu :

a. Layanan on-demand

Pelanggan dapat menentukan kapabilitas komputasi secara otomatis tanpa memerlukaninteraksi dengan provider layanan.

b. Akses jaringan secara luas

Layanan dapat diakses dari berbagai standar platform melalui jaringan internet.

\section{c. Sumber daya komputasi terpusat}

Sumber daya komputasi dikumpulkan pada satu lokasi untuk melayani beberapa konsumen menggunakan model multi-tenant, dengan sumber daya fisik dan virtual berbeda yang diterapkan secara dinamis sesuai dengan permintaan pelanggan

d. Elastisitas penyediaan sumber daya komputasi secara cepat

Penyediaan atau pengurangan sumber daya komputasi dapat disesuaikan dengan kebutuhan pelanggan. 


\section{e. Layanan yang terukur}

Cloud computing secara otomatis mengontrol dan mengoptimalkan penggunaan sumber daya komputasi dengan meningkatkan kemampuan pengukuran pada beberapa tingkat abstraksi yang sesuai dengan jenis layanan.

\section{METODE}

Metode penelitian yang digunakan di dalam penelitian ini, diantaranya adalah :

\section{a. Observasi}

Observasi digunakan untuk mendapatkan data mengenai penggunaan cloud computing Google drive, Drop Box, dan One Drive menggunakan kuisioner yang berisi opsi jawaban ya dan tidak.

b. Studi pustaka

Data dan informasi yang diperoleh melalui studi pustaka bersifat sekunder yaitu data yang diperoleh melalui studi literature, jurnal, bukubuku dan tulisan ilmiah tentang cloud computing.

sedangkan tahapan dari penelitian yang dilakukan adalah sebagai berikut:

a. Studi pustaka mengenai karateristik penyimpanan berbasis cloud.

b. Setelah mendapatkan data terkait karateristik penyimpanan berbasis Cloud langkah selanjutnya adalah penyusunan kuisioner.

c. Kuisioner disebar ke 10 sampel koresponden Data dari kuisioner diolah dan dianalisa menjadi informasi berupa hasil penelitian dankesimpulan.

Analisa mengenai penggunaan dari ketiga penyimpanan berbasis cloud, (Google Drive, drop Box, dan One Drive) ini nantinya dijadikan sebuah informasi yang dapat digunakan untuk mengambil sebuah kebijakan.

\section{HASIL}

Hasil dari studi pustaka disusun sebuah kuisioner dengan poin pertanyaan sebanyak 5 butir, yang ditujukan kepada penyimpanan berbasis Cloud Google Drive, Drop Box, dan One Drive, dimana rincian dari pertanyaan dari kuisioner dapat dilihat pada tabel dibawah ini .
Tabel.1 Kuisioner Penerapan Cloud Storage di

Fakultas Teknik Universitas PGRI Madiun

\begin{tabular}{|c|l|}
\hline No & \multicolumn{1}{|c|}{ Pertanyaan } \\
\hline 1 & Penyimpanan mudah digunakan \\
\hline 2 & Fitur lengkap \& sesuai dengan kebutuhan \\
\hline 3 & memiliki kapasitas penyimpanan yang cukup \\
\hline 4 & Tersinkronisasi dengan perangkat lain \\
\hline 5 & Aman untuk penyimpanan \& Sharing data \\
\hline
\end{tabular}

Hasil dari penyebaran kuisioner dari 10 sampel responden dosen dan mahasiswa didapat prosentase $86 \%$ setuju \& $14 \%$ tidak setuju bahwa Drop Box merupakan penyimpanan berbasis cloud yang mudah digunakan, berfitur lengkap, berkapasitas cukup, tersinkronisasi, dan aman untuk data sharing.

Hasil dari penyebaran kuisioner dari 10 sampel responden dosen dan mahasiswa didapat prosentase $82 \%$ setuju \& $12 \%$ tidak setuju bahwa Google Drive merupakan penyimpanan berbasis cloud yang mudah digunakan, berfitur lengkap, berkapasitas cukup, tersinkronisasi, dan aman untuk data sharing.

Hasil dari penyebaran kuisioner dari 10 sampel responden dosen dan mahasiswa didapat prosentase $58 \%$ setuju \& $42 \%$ tidak setuju bahwa One Drive merupakan penyimpanan berbasis cloud yang mudah digunakan, berfitur lengkap, berkapasitas cukup, tersinkronisasi, dan aman untuk data sharing. Keseluruhan hasil penyebaran kuisioner dapat dilihat pada grafik di bawah ini :

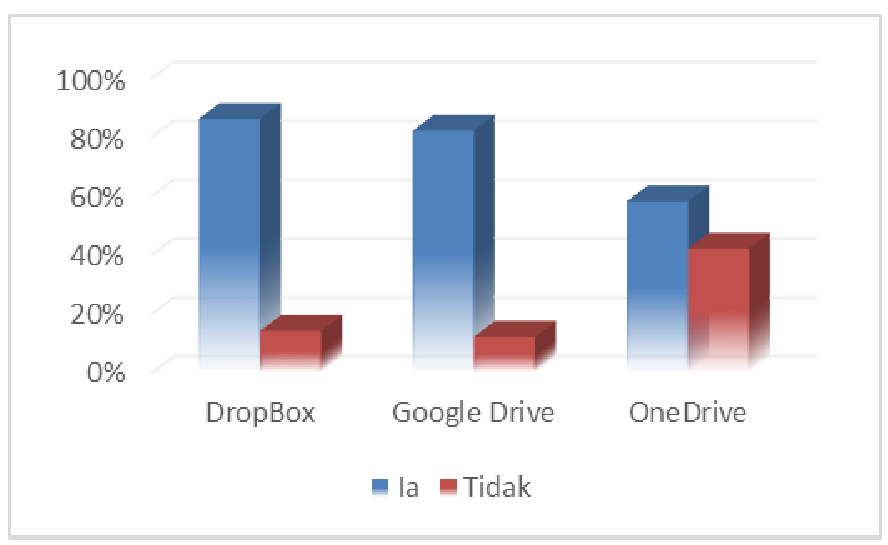

Gambar.1 Hasil Kuisioner Penerapan Cloud Storage di Fakultas Teknik Universitas PGRI Madiun 
Dari penyebaran kuisioner tersebut dapat diketahui bahwa Drop Box memiliki prosentase paling tinggi yaitu sebesar $86 \%$ dibandingkan dengan Google drive yang memiliki prosentase $82 \%$, dan prosentase dari One Drive $56 \%$.

\section{Kesimpulan}

Dari hasil penyebaran kuisioner mengenai penerapan Cloud storage di Fakultas Teknik Universitas PGRI Madiun didapat prosentase pengguna sebesar $86 \%$ setuju dan $14 \%$ setuju bahwa Drop Box merupakan penyimpanan berbasis cloud yang mudah digunakan, berfitur lengkap, berkapasitas cukup, tersinkronisasi, dan aman untuk data sharing. Dibandingkan dengan Google Drive dan One Drive. Tetapi berdasarkan jumlah penggunanya Google Drive lebih banyak digunakan dibandingkan DropBox dan One Drive.

\section{Daftar Pustaka}

[1] D. Setiawan, N. Asnawi, and H. A. Mumtahana, "EVALUATION OF STYLE-TEACHING LECTURERS INFORMATICS ENGINEERING STUDY PROGRAM UNIPMA IN TREND EDUCATION BASED ON TECHNOLOGY," Int. Conf. Educ. Sci., pp. 1168-1173, 2017.

[2] D. Setiawan, "PERSPEKTIF E-LEARNING DOSEN PROGRAM STUDI SISTEM INFROMASI UNIPMA," Res. J. Comput. Inf. Syst. \&technologymanagement, vol. 1, no. 2, pp. $1-6,2018$.

[3] R. Pamungkas, "OPTIMALISASI QUERY DALAM BASIS DATA MY SQL MENGGUNAKAN INDEX," Res. J. Comput. Inf. Syst. Technol. Manag., vol. 1, no. 1, pp. 2731, 2018.

[4] E. Y. Anggraini et al., "Aplikasi Penjadwalan Tugas berbasis Mobile Device Didukung Google Task dan Google Drive."

[5] A. Raziq and E. Marlina, "Pengelolaan Data Penelitian berbasis Komputasi Awan," SoSDict J. Pengabdi. Masy., vol. 1, no. 1, pp. 1-5, 2018.

[6] M. R. Effendi, "PENERAPAN TEKNOLOGI CLOUD COMPUTING DI UNIVERSITAS (Studi Kasus: Fakultas Teknologi Informasi Universitas Bayangkara Jakarta)," J. Teknol. Informasi1 2, vol. 12, no. 1, pp. 7-14, 2016.
[7] D. Yulistyanti, "Kajian Penerimaan Aplikasi Dropbox Dalam Pekerjaan Kelompok Siswa: Studi Kasus Smk Setia Negara Depok," vol. 7, no. 1, pp. 15-28, 2016. 